\title{
Analisis Isi Buku Teks Matematika Terbitan Erlangga Kelas VIII Semester I Berdasarkan Pendekatan Saintifik
}

\author{
Youla Siscasari $\mathbf{R}^{1}$, Hari Sumardi ${ }^{2}$, Nur Aliyyah Irsal ${ }^{3}$ \\ 1,2,3 Prodi Pendidikan Matematika, FKIP, Universitas Bengkulu, Bengkulu-Indonesia \\ Email: ysiscasari11@gmail.com
}

\begin{abstract}
ABSTRAK
Buku teks matematika merupakan bahan ajar mata pelajaran matematika yang disusun berdasarkan Kurikulum 2013 sebagai pegangan peserta didik dengan tujuan untuk membantu peserta didik dalam proses belajar matematika. Penelitian ini bertujuan untuk mendeskripsikan kesesuain Buku Teks Matematika untuk SMP/MTS Kelas VIII Semester 1 Terbitan Erlngga yang disusun oleh M.Cholik Adinawan dengan menggunakan Pendekatan Saintifik. Jenis penelitian yang digunakan adalah Penelitian Deskriptif. Dalam penelitian ini menggunakan dua teknik pengumpulan data yaitu dokumentasi dan lembar observasi. Instrumen penelitian yang digunakan adalah lembar penskoran kesesuain buku. Hasil analisis kesesuaian penyajian materi pada buku teks matematika kelas VIII terbitan Erlangga berdasarkan pendekatan saintifik pada bab relasi dan fungsi memperoleh persentase akhir 57,53\% dengan kriteria cukup sesuai. Persentase tahap mengamati $83,93 \%$, tahap menanya $39,29 \%$, tahap mengumpulkan informasi $77,29 \%$, tahap menalar $21,43 \%$, dan tahap mengkomunikasikan 66,86\%. Pada bab sistem persamaan linear dua variabel memperoleh persentase akhir $52,41 \%$ dengan kriteria cukup sesuai, persentase tahap mengamati $57,30 \%$, tahap menanya $22,20 \%$, tahap mengumpulkan informasi $72,91 \%$, tahap menalar $33,16 \%$, dan tahap mengkomunikasikan $72,17 \%$. Dapat disimpulkan bahwa pada buku ini pendekatan saintifik belum disampaikan secara keseluruhan, masih terdapat tahapan saintifik yang tidak terlihat jelas. Berdasarkan penelitian tersebut disarankan untuk melengkapi tahapan saintifik agar sesuai dengan kurikulum 2013.
\end{abstract}

Kata kunci: Analisis, Buku Teks Matematika, Pendekatan Saintifik

\begin{abstract}
Mathematics textbooks are teaching materials of mathematics subjects that are prepared based on curriculum 2013 as a handle for students with the aim to help learners in the process of learning mathematics. This study aims to describe the similarity of Mathematics Textbooks for SMP/MTS Grade VIII Semester 1 published by M.Cholik Adinawan using a Scientific Approach. The type of research used is Descriptive Research. This study used two data collection techniques, namely documentation and observation sheets. The research instrument used is the book's corresponding score sheet. The results of the analysis of the suitability of the presentation of materials in the mathematics textbook class VIII issued by Erlangga based on scientific approaches in the chapter on relationships and functions obtained a final percentage of $58.76 \%$ with sufficient criteria. The percentage of the stage observed $83.93 \%$, the question stage $39.29 \%$, the stage of gathering information $77.29 \%$, the stage of reasoning $21.43 \%$, and the stage of communicating $66.86 \%$. In the linear equation system chapter two variables obtained a final percentage of $54 \%$ with sufficient criteria accordingly, the percentage of the observing stage $57.30 \%$, the questioning stage of $22.20 \%$, the stage of gathering information $72.91 \%$, the stage of measuring $33.16 \%$, and the stage of communicating $72.17 \%$. It can be concluded that in this book the scientific approach has not been conveyed in its entirety, there are still scientific stages that are not clearly visible. Based on the research is recommended to complete the scientific stages to fit the curriculum 2013.
\end{abstract}

Keywords: Analysis, Mathematics Textbook, Scientific Approach 


\section{A. Pendahuluan}

Matematika salah satu ilmu dasar yang mempunyai peranan yang penting dalam suatu upaya dalam memajukan bidang ilmu pengetahuan dan teknologi. Matematika merupakan pelajaran yang sangat penting sehingga tidak bisa dipungkiri bahwa matematika sangat dibutuhkan dalam suatu proses pengetahuan. Kurikulum 2013 memiliki salah satu tujuan melalui pembelajaran matematika yaitu memahami konsep matematika, menjelaskan keterkaitan antara konsep serta mengaplikasikan konsep atau logaritma secara luwes, akurat, efisien, serta tepat dalam suatu proses pemecahan masalah (Latif et al., 2016). Maka dari itu, matematika merupakan suatu yang sangat berperan dalam kehidupan sehari-hari. Berkaitan dengan hal tersebut, akan tetapi, di Indonesia sampai saat ini pelajaran matematika masih kurang diminati oleh peserta didik, sehingga prestasi belajar matematika di sekolah masih tergolong rendah.

Berdasarkan hasil survei Programme for Internatinal Student Assesment (PISA) pada tahun 2018 yang diselenggarakan oleh Organization for Economic Co-Operation and Development (OECD) Indonesia menduduki peringkat yang berada dalam urutan bawah, yaitu untuk nilai matematika meduduki peringkat 72 dari 78 negara (Schleicher, 2018). Kemudian, fakta lainnya dari hasil TIMSS menunjukkan bahwa dari Indonesia peserta didik hanya unggul ketika mengerjakan soal yang teoritis serta bersifat hafalan, akan tetapi lemah ketika dihadapkan dengan soal yang memerlukan kompetensi untuk mengungkapkan yang termasuk dalam aspek tingkat tinggi, yakni salah satunya adalah soal yang memerlukan aplikasi (appliying) serta penalaran (reasoning) (Mukaromah, 2020). Pada kondisi tersebut menunjukkan bahwa pendidikan matematika di Indonesia masih jauh dari yang diharapkan. Maka dari itu, pentingnya perbaikan dalam usaha meningkatkan kualitas pembelajaran matematika. Penunjang untuk meningkatkan kualitas pembelajaran matematika salah satunya yaitu menggunakan sumber berupa buku teks. Pada Kurikulum 2013 ini pemerintah telah menyediakan buku guru serta buku siswa sebagai salah satu sumber yang dapat digunakan dalam proses belajar dengan menggunakan Pendekatan Saintifik.

Kurikulum 2013 diimplementasikan dalam proses pembelajaran dengan pendekatan saintifik merupakan salah satu proses dalam pembelajaran yang dirancang sedemikian rupa yang gunanya agar peserta didik dapat secara aktif mengonstruk konsep, hukum atau prinsip melalui tahapantahapan atau proses yang salah satu nya yaitu mengamati yang berguna (untuk mengidentifikasi atau menemukan masalah), merumuskan masalah, mengajukan atau merumuskan hipotesis, mengumpulkan data melalui berbagai macam teknik, menganalisis data, menarik suatu kesimpulan serta mengkomunikasikan konsep hukum atau prinsip yang "ditemukan" (Hosnan, 2014:34). Pendekatan Saintifik salah satunya terdapat kegiatan berupa 5M yaitu (mengamati, menanya, mengumpulkan informasi, menalar, dan mengkomunikasikan). Dalam suatu kegiatan mengamati proses pembelajaran peserta didik tidak hanya fokus dalam memperhatikan suatu masalah saja, akan tetapi peserta didik diharapkan dapat mampu dalam membuat sebuah kesimpulan dari suatu masalah tersebut. Dalam suatu kegiatan menanya, proses pembelajaran pada peserta didik yaitu mengajukan informasi yang tidak dipahami dari apa yang telah diamati. Setelah, selanjutnya yaitu melakukan suatu kegiatan mengumpulkan berupa informasi yang dilakukan dengan menggali dan mengumpulkan informasi dari berbagai macam sumber. Langkah selanjutnya, yaitu menalar serta mengkomunikasikan. Keunggulan buku dengan menggunakan salah satu pendekatan yaitu Pendekatan Saintifik adalah: (1) memandu peserta didik dalam memecahkan masalah melalui suatu kegiatan dalam sebuah proses perencanaan yang matang, pengumpulan data, serta berupa analisis data untuk menghasilkan suatu kesimpulan; (2) menuntun peserta didik untuk berpikir secara sistematis, kritis, kreatif, serta melakukan aktivitas berupa penelitian serta membangun sebuah konseptualisasi pengetahuan; (3) membina kepekaan peserta didik terhadap sebuah problematika yang terjadi di dalam lingkungan peserta didik itu sendiri; (4) membina kemampuan peserta didik dalam membuat argumentasi serta komunikasi; dan yang terakhir yaitu (5) mengembangkan sebuah karakter dalam diri peserta didik (Aprianita, 2015).

Penelitian mengenai analisis buku teks telah dilakukan sebelumnya oleh penelitian dari Hisbiatul (2020) dalam penelitiannya menunjukkan hasil bahwa analisis kesesuaian buku dengan pendekatan saintifik, buku peserta didik terbitan Kemendikbud edisi revisi 2017 kelas VII SMP pelajaran matematika semester I 
kesesuaian sebesar $88 \%$ dengan kategori sangat baik. Maka dari itu, berdasarkan latar belakang yang telah dijelaskan, maka penelitian ini bertujuan untuk mengkaji tentang suatu kesesuaian penyajian materi yang berada pada buku teks matematika terbitan Erlangga Kelas VIII semester I kurikulum 2013 materi relasi fungsi dan sistem persamaan linear dua variabel dengan pendekatan saintifik.

\section{B. Metode Penelitian}

Penelitian dalam menganalisis isi buku teks matematika ini menggunakan jenis penelitian deskriptif dengan menggunakan suatu pendekatan yaitu pendekatan kualitatif. Penelitian ini termasuk kedalam penelitian deskriptif karena dalam penelitian ini dilakukan suatu analisis yang digunakan untuk menggambarkan atau mendeskripsikan sebuah persentase terhadap kesesuain buku.

Langkah-langkah yang digunakan dalam proses penelitian ini sebagai berikut, yaitu :

1. Memilih suatu buku teks pelajaran matematika yang akan dianalisis yaitu Buku Teks Matematika Kelas VIII Semester I Kurikulum 2013 Edisi Revisi 2016 terbitan Erlangga.

2. Studi pustaka Pendekatan Saintifik berdasarkan tahapan-tahapan secara tertulis di buku ataupun di jurnal untuk mempermudah penelitian.

3. Menyusun instrumen berdasarkan pendekatan saintifik yang menggunakan instrument yakni lembar observasi

4. Memvalidasi lembar observasi oleh ahli agar bisa digunakan untuk penelitian. Pada validasi oleh ahli memberikan komentar dan saran untuk diperbaiki.

5. Memberikan lembar observasi dan buku yang akan diteliti pada teman sejawat dengan beberapa kriteria yaitu : (1) telah menempuh pendidikan S1 Matematika; (2) sedang mengajar di SMP/MTS atau SMA/SMK; dan (3) sudah pernah menganalisis buku teks .

6. Pengumpulan data dilakukan dengan cara memberikan penilaian pada setiap subbab dalam bab relasi fungsi dan sistem persamaan linear dua variabel pada buku matematika kelas VIII semester 1 Kurikulum 2013 revisi terbitan Erlangga berdasarkan Pendekatan Saintifik oleh peneliti dan teman sejawat.

7. Menganalisis data dengan memperhatikan tahapan pendekatan saintifik dan mendeskripsikan hal-hal yang perlu di perbaiki penyajian materi pada buku teks sesuai pendekatan saintifik.

8. Membuat kesimpulan dari menganalisis data yang di dapat untuk mengetahui perbaikan di setiap subbab dalam bab relasi fungsi dan sistem persamaan linear dua variabel berdasakan pendekatan saintifik.

Sumber data dalam penelitian analisis ini adalah buku teks matematika untuk siswa SMP kelas VIII semester 1 terbitan Erlangga dengan menggunakan pendekatan Saintifik, yang akan dianalisis pada Bab Relasi Fungsi dan Sistem Persamaan Linear Dua Variabel. Pengumpulan data yang digunakan dalam penelitian ini yaitu menggunakan metode dokumentasi serta lembar observasi. Lembar observasi dalam penelitian ini merupakan instrument penelitian yang terdiri dari 11 pernyataan mengenai tahapan Pendekatan Saintifik. Instrumen penelitian ini berbentuk check-list atau daftar centang serta berupa keterangan.

Analisis data dalam penelitian ini yaitu dengan cara menganalisis data-data yang telah terkumpul dengan menggunakan kriteria penskoran dan kategori kesesuaian buku.

1. Kriteria Penskoran

Pada lembar observasi penelitian ini penskoran menggunakan skor $0,1,2$ dengan cara check-list $(\checkmark)$ pada salah satu kriteria yang memenuhi pernyataan pada langkahlangkah pendekatan saintifik pada sub pokok yang akan dianalisis. Apabila skor bernilai 0 jika tidak ada (aspek yang diteliti tidak sesuai dengan pernyataan yang diberikan), skor bernilai 1 jika ada dan tidak jelas, skor bernilai 2 jika ada dan cukup jelas. Setelah diberi skor pada setiap pernyataan, maka dihitung persentasenya.

2. Kategori Kesesuain Buku

Kategori persentase kesesuain tahap pendekatan saintifik pada buku teks matematika diterapkan dalam tabel berikut ini.

Tabel 1. Kategori Kesesuain Buku

\begin{tabular}{|c|c|}
\hline Persentase (p) & Kategori \\
\hline $\mathrm{p} \geq 80$ & Sangat Sesuai \\
\hline $60 \leq \mathrm{p}<80$ & Sesuai \\
\hline $50 \leq \mathrm{p}<60$ & Cukup Sesuai \\
\hline $\mathrm{p}<50$ & Tidak Sesuai \\
\hline
\end{tabular}

Sumber : (Lya \& Pramesti, 2017)

Selanjutnya hasil penelitian kesesuain pada buku teks matematika SMP kelas VIII terbitan Erlangga akan dilakukan pengujian keabsahan 
data yang dinilai oleh pengamat dengan menggunakan uji kesepakatan (uji kappa). Di uji keabsahan datanya menggunakan uji kesepakatan (uji kappa) dengan rumus sebagai berikut:

Keterangan:

$$
\mathrm{k}=\frac{P(a)-P(e)}{1-P(e)}
$$

\section{$\mathrm{k} \quad$ : Indeks kappa}

$p$ (a): persentase jumlah pengukuran yang konsisten antar penilai/ pengamat/ teman sejawat.

$p \quad(e)$ : persentase jumlah perubahan pengluran. Berikut interpretasi nilai Kappa berdasarkan (Fleis dalam Napitupula, 2017:74) disajikan pada tabel berikut ini.

\section{Tabel 2. Interpretasi Kappa}

\begin{tabular}{|c|c|}
\hline Indeks Kappa & Kategori \\
\hline $\mathrm{k}<0.40$ & Buruk \\
\hline $0.40<\mathrm{k} \leq 0.60$ & Cukup \\
\hline $0.60<\mathrm{k} \leq 0.75$ & Baik \\
\hline $\mathrm{k}>0,75$ & Sangat Baik \\
\hline
\end{tabular}

Keterangan:

Sumber: (Napitupulu, 2014)

1. Jika indeks kappa $\mathrm{k}<0.40$ maka kategori kesesuaian hasil analisis antara peneliti dan teman sejawat adalah buruk, sehinnga perlu di analisis kembali.

2. Jika indeks kappa $0.40<\mathrm{k} \leq 0.60$ maka kategori kesesuaian hasil analisis antara peneliti dan teman sejawat adalah cukup sehingga analisis diterima.

3. Jika indeks kappa $0.60<\mathrm{k} \leq 0.75$ maka kategori kesesuaian hasil analisis antara peneliti dan teman sejawat adalah baik sehingga analisis diterima.

4. Jika indeks kappa $\mathrm{k}>0,75$ maka kategori kesesuaian hasil analisis antara peneliti dan teman sejawat adalah sangat baik sehingga analisis diterima.

\section{Hasil dan Pembahasan}

Sebelum melakukan suatu proses penelitian, lembar instrumen terlebih dahulu di validasi oleh validator. Validator dalam instrumen ini terdiri dari dua orang validator yang merupakan dosen yang berasal dari program studi Pendidikan Matematika. Validasi ini dilakukan dengan menggunakan sebuah instrumen berupa lembar validasi yang berupa angket penilaian dengan menggunakan skala. Instrumen penelitian ini dalam penilaiannya diambil setelah dilakukan beberapa revisi yang berdasarkan masukan dari validator terhadap instrumen yang akan digunakan. Adapun revisi tersebut sebagai berikut, adalah:

\section{Revisi Validator I}

a. Indikator no 3 yang awalnya ada di tahapan mengamati yaitu objek yang diamati menimbulkan tantangan untuk peserta didik bertanya sebaiknya masuk pada tahapan bertanya.

b. Indikator no 8 pada tahapan menalar (kegiatan yang mendorong peserta didik untuk melakukan percobaan agar dapat menarik kesimpulan) saran validator percobaan lebih sesuai untuk mengumpulkan informasi. Hasil percobaan digunakan dalam proses menalar, bukan proses percobaannya. Maka diganti dengan indikator menyajikan pertanyaan atau masalah yang harus di jawab sehingga dapat mendorong peserta didik menarik kesimpulan.

c. Sebaiknya tambahkan indikator tahap "menyimpulkan". Setelah di ditambahkan indikator menyimpulkan yaitu terdapat kegiatan peserta didik untuk mengkomunikasikan kesimpulan pada setiap subsub bab materi.

\section{Revisi Validator II}

a. Pada indikator no 3 yang awalnya ada di tahapan mengamati (objek yang diamati menimbulkan tantangan untuk peserta didik bertanya) sudah masuk pada tahapan bertanya.

b. Indikator tahap menanya sebelum revisi pada no 4 dan no 5 yang terdapat pada lampiran 5 yaitu terdapat suatu proses kegiatan yang bertujuan mengajak peserta didik untuk dapat merumuskan sebuah pertanyaan mengenai informasi yang tidak dapat dipahami dari apa yang telah diamati. Terdapat suatu kegiatan yang menagajak peserta didik untuk dapat mengajukan sebuah pertanyaan guna mendapatkan informasi pendukung tambahan mengenai apa yang telah diamati. Karena menurut validator II ini indikatornya hampir sama maka dihapus salah satu agar hasilnya tidak bias.

Dan sesudah revisi hanya indikator no 4 yang diambil yaitu terdapat kegiatan yang mengajak peserta didik untuk merumuskan pertanyaan tentang informasi yang tidak dipahami dari apa yang diamati. 
c. Indikator no 5 pada tahapan mengumpulkan informasi sebelum revisi yaitu terdapat suatu kegiatan yang gunanya mendorong peserta didik agar dapat mengumpulkan sebuah informasi dari berbagai macam sumber, saran dari validator untuk indikator ini adalah bukan pada proses kegiatan, akan tetapi lebih kepada data atau informasinya. Maka setelah direvisi menjadi terdapat objek atau masalah yang mendorong peserta didik untuk mengumpulkan data dari mengamati dan menanya.

d. Indikator no 8 pada tahapan kegiatan menalar sebelum revisi yaitu terdapat suatu kegiatan yang gunanya agar mendorong peserta didik untuk melakukan suatu percobaan agar dapat menarik suatu kesimpulan. Saran dari validator untuk indikator ini bukan berfokus pada kegiatan tapi kepada data atau informasinya. Setelah di revisi menjadi menyajikan pertanyaan atau masalah yang harus di jawab sehingga dapat mendorong peserta didik dalam menarik suatu kesimpulan.

Pokok bahasan yang dianalisis pada suatu penelitian ini adalah berjumlah 13 suatu pokok bahasan. Dimana terdapat 7 pokok bahasan dalam bab relasi dan fungsi serta 6 pokok bahasan pada bab sistem persamaan linear dua variabel.

\section{a) Bab Relasi dan Fungsi}

Hasil dari analisis kesesuaian pada bab relasi dan fungsi yaitu berdasarkan dari pendekatan saintifik yaitu sebagai berikut.
Tabel 3. Hasil Analisis Bab Relasi dan Fungsi

\begin{tabular}{|c|c|c|c|c|c|c|}
\hline \multirow{2}{*}{$\begin{array}{c}\text { Subab } \\
\text { yang } \\
\text { diteliti }\end{array}$} & \multicolumn{5}{|c|}{ Rata-rata tahapan saintifik } & \multirow{2}{*}{$\begin{array}{c}\text { Persent } \\
\text { ase }\end{array}$} \\
\hline & M1 & M2 & M3 & M4 & M5 & \\
\hline Relasi & $100 \%$ & $50 \%$ & $75 \%$ & $12,5 \%$ & $75 \%$ & $62,5 \%$ \\
\hline $\begin{array}{c}\text { Fungsi } \\
\text { atau } \\
\text { pemeta } \\
\text { an } \\
\end{array}$ & $100 \%$ & $50 \%$ & $83,3 \%$ & $75 \%$ & $94,4 \%$ & $80,32 \%$ \\
\hline $\begin{array}{c}\text { Koresp } \\
\text { ondensi } \\
\text { satu- } \\
\text { satu }\end{array}$ & $100 \%$ & $50 \%$ & $100 \%$ & $12,5 \%$ & $83,3 \%$ & $69,16 \%$ \\
\hline $\begin{array}{l}\text { Notasi } \\
\text { fungsi }\end{array}$ & $100 \%$ & $50 \%$ & $75 \%$ & $25 \%$ & $16,6 \%$ & $53,32 \%$ \\
\hline $\begin{array}{l}\text { Nilai } \\
\text { fungsi }\end{array}$ & $62,5 \%$ & $25 \%$ & $62,5 \%$ & $0 \%$ & $66,6 \%$ & $40,82 \%$ \\
\hline $\begin{array}{l}\text { Grafik } \\
\text { fungsi }\end{array}$ & $100 \%$ & $50 \%$ & $100 \%$ & $25 \%$ & $66,6 \%$ & $68,32 \%$ \\
\hline $\begin{array}{c}\text { Penerap } \\
\text { an } \\
\text { relasi } \\
\text { dan } \\
\text { fungsi } \\
\end{array}$ & $25 \%$ & $0 \%$ & $50 \%$ & $0 \%$ & $66,6 \%$ & $28,32 \%$ \\
\hline $\begin{array}{c}\text { Rata- } \\
\text { rata }\end{array}$ & $83,93 \%$ & $39,29 \%$ & $77,97 \%$ & $21,43 \%$ & $67,01 \%$ & $57,53 \%$ \\
\hline
\end{tabular}

Keterangan:

M1 : Mengamati

M2: Menanya

M3 : Mengumpulkan Informasi

M4: Menalar

M5: Mengkomunikasikan

\section{b) Bab Sistem Persamaan Linear Dua Variabel}

Hasil dari analisis kesesuaian pada bab sistem persamaan linear dua variabel yang berdasarkan pada pendekatan saintifik yaitu sebagai berikut.

Tabel 4. Hasil Analisis Bab SPLDV

\begin{tabular}{|l|c|c|c|c|c|c|}
\hline \multirow{2}{*}{$\begin{array}{c}\text { Subab } \\
\text { yang } \\
\text { diteliti }\end{array}$} & \multicolumn{5}{|c|}{ Rata-rata tahapan saintifik } & \multirow{2}{*}{$\begin{array}{c}\text { Perse } \\
\text { ntase }\end{array}$} \\
\cline { 2 - 6 } $\begin{array}{l}\text { Persam } \\
\text { aan } \\
\text { linear } \\
\text { dua } \\
\text { variabel } \\
\text { (PLDV) }\end{array}$ & $100 \%$ & $50 \%$ & $100 \%$ & $66,6 \%$ & $66,6 \%$ & $76,64 \%$ \\
\hline $\begin{array}{l}\text { SPLDV } \\
\text { Menyel } \\
\text { saikan } \\
\text { SPLDV }\end{array}$ & $56,25 \%$ & $25 \%$ & $62,5 \%$ & $37,5 \%$ & $66,6 \%$ & $49,57 \%$ \\
\hline $\begin{array}{l}\text { SPLDV } \\
\text { dengan } \\
\text { pecahan }\end{array}$ & $25 \%$ & $33,3 \%$ & $100 \%$ & $100 \%$ & $100 \%$ & $81,66 \%$ \\
\hline $\begin{array}{l}\text { Penerap } \\
\text { an } \\
\text { SPLDV }\end{array}$ & $62,5 \%$ & $25 \%$ & $75 \%$ & $0 \%$ & $66,6 \%$ & $50 \%$ \\
\hline $\begin{array}{l}\text { Sistem } \\
\text { persam } \\
\text { aan } \\
\text { nonline } \\
\text { ar dua } \\
\text { variabel }\end{array}$ & $25 \%$ & $0 \%$ & $50 \%$ & $0 \%$ & $66,6 \%$ & $8,32 \%$ \\
\hline $\begin{array}{l}\text { Rata- } \\
\text { rata }\end{array}$ & $57,30 \%$ & $22,21 \%$ & $72,9 \%$ & $34,01 \%$ & $72,17 \%$ & $52,41 \%$ \\
\hline
\end{tabular}


Keterangan:

M1 : Mengamati

M2: Menanya

M3 : Mengumpulkan Informasi

M4: Menalar

M5: Mengkomunikasikan

\section{c) Hasil Analisis Keabsahan Data}

Hasil dari analisis uji kappa pada penelitian ini yaitu pada setiap pokok bahasan dalam suatu bab relasi dan fungsi serta sistem persamaan linear dua variabel yaitu terdapat pada data tabel dibawah ini.

Tabel 5. Hasil Analisis Uji Kappa

\begin{tabular}{|c|c|c|c|}
\hline $\begin{array}{c}\text { Subbab } \\
\text { yang diteliti }\end{array}$ & $\begin{array}{c}\text { Nilai } \\
\text { Kappa }\end{array}$ & Signifikan & $\begin{array}{c}\text { Keeratan } \\
\text { keabsahan } \\
\text { Data }\end{array}$ \\
\hline Relasi & 0,628 &, 000 & Baik \\
\hline $\begin{array}{c}\text { Sistem } \\
\text { persamaan } \\
\text { linear dua } \\
\text { variabel }\end{array}$ & 0,663 &, 000 & Baik \\
\hline
\end{tabular}

Berdasarkan tabel diatas menunjukkan bahwa pada setiap indikator (pernyataan) penilaian antara peneliti dan teman sejawat mempunyai keeratan keabsahan data pada materi relasi dan fungsi adalah 0,628 dan pada materi SPLDV adalah 0,663 nilai kappa ini termasuk kriteria baik. Hasil analisis keabsahan data antara peneliti dan teman sejawat pada bab relasi dan fungsi diperoleh bahwa dari 13 subsub bab terdapat 1 subsub bab yaitu merumuskan suatu fungsi yang memiliki kesamaan dengan total skor 11 dan terdapat 12 subsub bab perbedaan pada hasil analisis kesesuaian buku. Pada sebuah bab sistem persamaan linear dua variabel diperoleh sebuah hasil yang menyatakan bahwa dari 14 subsub bab terdapat 3 subsub bab yang memiliki suatu kesamaan yaitu pada pengertian SPLDV dengan total skor 6 , penyelesaian atau akar SPLDV dengan total skor 6, dan metode grafik dengan total skor 20, serta terdapat 11 subsub bab perbedaan pada hasil analisis kesesuain buku.

Pada buku terbitan Erlangga, setiap materinya diawali dengan diberikan berupa objek yang dapat diamati, dari objek tersebut diharapkan peserta didik dapat bertanya dari apa yang diamati, buku ini juga memberikan penjelasan materi sebagai mengumpulkan informasi. Buku ini menyajikan kegiatan siswa untuk memandu siswa mengalami sebuah proses yang mengarah pada penemuan rumus atau kesimpulan, menyajikan tugas siswa diberikan agar siswa lebih aktif dalam memahami materi dan memecahkan masalah, serta meberikan latihan yang disajikan struktur dengan tingkat kesulitan bertahap agar peserta didik dapat melakukan tahapan menalar dan pada buku ini memberikan kesimpulan pada akhir penyajian materi sebagai mengkomunikasikan. Pada buku teks ini pada suatu tahapan saintifik tidak diberikan label atau judul untuk mengetahui setiap proses tahapannya, buku ini juga tidak disajikan urutan secara sistematis, yang dikarenakan pada penyajian bahan yang bermacam-macam, serta pola penyajian buku teks yang disesuaikan dengan proses perkembangan intelektual peserta didik sasaran. Hal ini juga sejalan dengan sebuah pendapat dari Muchlis yang mengatakan bahwa materi yang terdapat didalam buku teks diuraikan mengikuti pola penalaran tertentu, sebagaimana pola penalaran dalam sebuah sajian ilmiah, yaitu pola penalaran induktif, deduktif, atau campuran (kombinasi induktif-deduktif) (Eka Sofia Agustina, Farida Aryani, 2016). Manfaat dari materi ini disusun dengan menggunakan pendekatan saintifik, karena pendekatan saintifik memudahkan guru atau pengembang kurikulum dalam memperbaiki suatu proses pembelajaran, yaitu dengan cara memecah suatu proses ke dalam langkah-langkah atau tahapan-tahapan secara terperinci yang memuat sebuah instruksi untuk memudahkan peserta didik dalam melaksanakan proses pembelajaran. Sehingga dapat disebutkan bahwa pendekatan ini dapat mengaitkan antara matematika dengan ilmu pengetahuan, sehingga peserta didik akan secara menarik mempelajari matematika. Belajar dengan sebuah proses berkegiatan akan dapat berkontribusi terhadap pemahaman intuitif matematika pada peserta didik, dengan kata lain belajar matematika yang baik adalah salah satunya yaitu mengalami (melakukan tindakan) atau berkegiatan (melakukan suatu kegiatan) (Atsnan \& Gazali, 2013).

Hasil dari analisis data yang telah dilakukan yang terdapat pada bab relasi dan fungsi diketahui bahwa belum sepenuhnya terdapat proses atau tahapan pendekatan saintifik dalam menyajikan suatu materi, banyak sub bab yang masih belum terdapat pada tahapan saintifik sehingga hanya berupa sebuah uraian materi saja. Bab ini memang sudah menerapkan suatu pedekatan saintifik, akan tetapi pada bab ini 
masih belum sesuai pada proses tahapan menanya serta menalar. Pada tahapan menanya memperoleh persentase sebesar 39,29\%. Dikarenakan tidak adanya suatu proses kegiatan menanya yang terdapat pada buku teks serta objek yang diamati tidak menimbulkan kebingungan peserta didik untuk bertanya serta merumuskan suatu pertanyaan. Sebaiknya pada pada buku ini disajikan suatu kegiatan menanya mengenai hasil pada pengamatan yang telah dilakukan serta terdapat suatu ajakan yang gunanya untuk merumuskan suatu pertanyaan dari apa yang telah diamati sehingga dapat mendorong peserta didik untuk bertanya, kalimat ajakan tersebut harus dapat membangkitkan rasa ingin tahu peserta didik. Serta pada tahapan menalar memperoleh persentase sebesar $21,43 \%$, dikarenakan tidak adanya suatu kegiatan yang mendorong peserta didik untuk mengolah informasi yang sudah dikumpulkan serta tidak menyajikan masalah atau pertanyaan yang membuat peserta didik dapat menarik suatu kesimpulan. Misalnya pada sub bab penerapan relasi dan fungsi ini seharusnya diberikan latihan soal berupa sebuah kegiatan siswa untuk peserta didik dalam melakukan proses atau tahapan menalar dengan cara mengolah informasi yang sudah dikumpulkan serta dapat menarik kesimpulan dari jawabannya, dengan begitu dapat pula diharapkan membantu peserta didik lebih memahami materi pelajaran. Begitupun untuk sub bab lainnya harus menyajikan proses kegiatan siswa agar dapat memandu peserta didik untuk menalar, sehingga dapat mengarah pada suatu proses penemuan. Kepada tahapan mengamati pada bab ini, proses kegiatan mengamati sangat bagus untuk menuntun peserta didik dalam membangun sebuah pengetahuannya sendiri, menemukan sesuatu sampai dengan memahami sebuah nilai dari proses pengetahuan, sikap, serta keterampilan.

\section{Kesimpulan dan Saran}

\section{Kesimpulan:}

Berdasarkan dari hasil penelitian serta pembahasan dalam analisis pada buku teks matematika SMP kelas VIII semester 1 terbitan Erlangga berdasarkan suatu pendekatan yaitu pendekatan saintifik dapat disimpulkan bahwa pada bab relasi dan fungsi memiliki suatu tingkat kesesuaian sebesar $57,53 \%$ dengan kategori cukup sesuai, tetapi pada bab ini terdapat subbab yang memiliki kategori sangat sesuai yaitu fungsi atau pemetaan dengan persentase $80,32 \%$.
Persentase tahap mengamati $83,93 \%$, tahap menanya $39,29 \%$, tahap mengumpulkan informasi $77,97 \%$, tahap menalar $21,43 \%$, dan tahap mengkomunikasikan $67,01 \%$. Jadi, pada bab ini lebih banyak pada tahapan mengamati, kurang pada pada tahapan menanya dan menalar. Dan bab sistem persamaan linear dua variabel memiliki tingkat kesesuain sebesar 52,41\% kategori cukup sesuai tetapi pada bab ini terdapat subbab yang memiliki kategori sangat sesuai yaitu menyelesaikan SPLDV dengan persentase $81,66 \%$. Persentase tahap mengamati $57,30 \%$, tahap menanya $22,21 \%$, tahap mengumpulkan informasi $72,91 \%$, tahap menalar $34,01 \%$, dan tahap mengkomunikasikan $72,17 \%$. Jadi, pada bab ini lebih banyak pada tahapan mengumpulkan informasi dan kurang pada tahapan menalar dan menanya.

\section{Saran}

Berdasarkan dari hasil analisis yang telah dilakukan terhadap kesesuaian materi yang berdasarkan pada pendekatan saintifik dalam buku teks matematika SMP kelas VIII semester 1 terbitan Erlangga, peneliti memiliki beberapa saran penelitian yaitu sebagai berikut: pada sub bab relasi dan fungsi sebaiknya banyak diberikan latihan soal disajikan dalam bentuk berupa kegiatan siswa, agar peserta didik dapat melakukan proses tahapan menanya serta menalar. Hal ini bertujuan agar peserta didik dapat mengkomunikasikan gagasannya secara tertulis dan secara lisan dan dapat menarik kesimpulan menurut peserta didik. Pada sub bab sistem persamaan linear dua variabel sebaiknya lebih banyak diberikan objek yang diamati sehingga peserta didik dapat menanya dari objek tersebut dan juga diberikan kegiatan siswa untuk peserta didik melakukan tahapan menalar. Hal ini bertujuan agar peserta didik dapat mengkomunikasikan gagasannya secara tertulis dan secara lisan dan dapat menarik kesimpulan menurut peserta didik. Ketidaksesuain serta saran perbaikan dari hasil analisis pada buku teks ini dapat dijadikan sebuah bahan pertimbangan serta perbaikan untuk penulis dan penerbit.

\section{E. Daftar Pustaka}

Aprianita, R. (2015). Menerapkan Pendekatan Saintifik yang Berorientasi pada Kemampuan Metakognisi dan Keterampilan Sosial. Seminar Nasioanl Matematika Dan Pendidikan Matematika UNY, 689-696. 
Atsnan, M. F., \& Gazali, R. Y. (2013). PENERAPAN PENDEKATAN SCIENTIFIC DALAM PEMBELAJARAN MATEMATIKA SMP KELAS VII MATERI BILANGAN ( PECAHAN ). Prosiding Seminar Nasional Matematika Dan Pendidikan Matematika, November, 978-979.

Daryanto. (2014). Pendekatan Pembelajaran Saintifik Kurikulum 2013. Yogyakarta: Gava Media.

Eka Sofia Agustina, Farida Aryani, dan Y. F. Y. (2016). POLA PENYAJIAN KEGIATAN PEMBELAJARAN BERBASIS PENDEKATAN ILMIAH. Yogyakarta: media akademi.

Hosnan. (2014). Pendekatan Saintifik dan Kontekstual Dalam Pembelajaran Abad 21. Bogor: Ghalia Indonesia.

Latif, S., Akib, I., \& Selatan, S. (2016). Mathematical Connection Ability In Solving Mathematics Problem Based On Initial Abilities Of Students At SMPN 10 BULUKUMBA. Jurnal Daya Matematis, 4(2), 207-217. https://doi.org/https;//doi.org/10.26858/jds.v $4 \mathrm{i} 2.2899$

Lya, S., \& Pramesti, D. (2017). Analisis materi dan penyajian buku teks matematika sebagai sumber belajar matematika. Jurnal Ilmiah Pendidikan Matematika, 5(1), 2532.

https://doi.org/http;//dx.doi.org/10.31941/de lta.v5i1.386

Mukaromah, H. (2020). ANALISIS BUKU TEKS MATEMATIKA KURIKULUM 2013 KELAS VII SEMESTER 1 EDISI REVISI 2017 DITINJAU DARI IMPLEMENTASI PENDEKATAN SAINTIFIK.

Muklis, Y. M. (2015). Analisis Buku Siswa Kurikulum 2013 Kelas VII SMP Pelajaran Matematika Ditinjau Dari Implementasi Pendekatan Saintifik dan Penilaian Autentik. Publikasi Ilmiah, 118.
Muslich, M. (2010). Text Book Writing. Jogjakarta: AR-RUZZ MEDIA.

Napitupulu, D. (2014). Studi Validitas dan Realibilitas Faktor Sukses Implementasi EGovernment Berdasarkan Pendekatan Kappa. Jurnal Sistem Informasi, 10(3), 70 74. https://doi.org/https://doi.org/10.21609/jsi.v $10 \mathrm{i} 2.388$

Schleicher, A. (2018). Insights and Interpretations. OECD.

Susiati, A., Utaya, S., \& Susilo, S. (2016). KAJIAN PENDEKATAN SAINTIFIK BUKU SISWA GEOGRAFI SMA BERDASARKAN KURIKULUM 2013. Jurnal Pendidikan: Teori, Penelitian, Dan Pengembangan, 1(8), 1505-1511. EISSN: 2502-47471X.

DOI:http://dx.doi.org/10.17977/jp.v1i8.662 1

Yudhanegarai \& Lestari, K. (2015). Penelitian Pendidikan Matematika. Bandung: PT Refika Aditama. 